\title{
Scientific memory from the early nineties; a common project with professors late János Gergely and Anna Erdei
}

\author{
Andras Falus $^{1}$ [D $\cdot$ Zsuzsa Bajtay $^{2}$
}

Received: 12 November 2020 / Accepted: 12 December 2020 / Published online: 10 January 2021

(c) The Author(s) 2021

\begin{abstract}
Based on the findings of common project 29 years ago, the Scandinavian J. of Immunology accepted and published our paper entitled by "Fc $\gamma$ R-Dependent Regulation of the Biosynthesis of Complement C3 by Murine Macrophages: the Modulatory Effect of IL-6" (Bajtay et al. in SJI 35:195-201, 1992). In this report we attempt to review the previous results and evaluate them with our current concepts on the interaction between the actors of adaptive and innate immunity. Let us first to summarize the basic results and consequences from the paper from 1992. Abstract from 1991-1992: The effect of murine IgG isotypes (myeloma proteins) on the gene expression and secretion of the third component of complement (C3) has been studied using the in monocytoid cell line P388D1 and oil-elicited mouse peritoneal macrophages. It is demonstrated that the binding of $\operatorname{lgG} 2 \mathrm{a}$ and $\lg \mathrm{G} 2 \mathrm{~b}$ but not $\mathrm{IgGl}$ and $\mathrm{IgG} 3$ isotypes augments the biosynthesis of $\mathrm{C} 3$ both in the presence and in the absence of the phorbol myristate acetate in the case of both cell types. The multifunctional cytokine inlerleukin-6 (IL-6) alone reveals no effect on the gene expression of $\mathrm{C} 3$, but facilitates the effectiveness of mouse IgG2a and IgG2b. Confirming the role of FcgRll, a strong up-regulation of gene expression and secretion of $\mathrm{C} 3$ was found when macrophages were co-cultured with the F(ab')2 fragment of the Fc $\gamma$ RII-specific monoclonal antibody 2.4 G2.
\end{abstract}

Keywords Fcgreceptor $\cdot$ Interleukin- $6 \cdot \mathrm{C} 3 \cdot$ Macrophage $\cdot \operatorname{IgG}$

\section{Introduction from 2020}

The bilateral interaction of innate and adaptive immunity is well documented in the last almost 30 years. In recent decades, a number of conceptual novelty have been elucidated and immunologists have recognized essential details in their assertion in immunity. Moreover the explosive development of molecular genetics and network sciences further clarified deep mechanisms of immunity both in health and disease. (Sjöholm et al 2006; Markiewski et al 2008; Holers 2014; Koenderman 2019).

Let us mention shortly just some of them.

Relatively new knowledge includes the recognition and categorization of innate lymphoid cell ILCs. A very significant paradigm shift, the description of receptors with limited

Andras Falus

afalus@gmail.com

1 Department of Genetics, Cell- and Immunobiology, Semmelweis University, Budapest, Hungary

2 Department of Immunology, MTA-ELTE Immunology Research Group, Eötvös University, Budapest, Hungary specificity (e.g. Toll-like receptors) on the surface of many cells of innate immunity (e.g. dendritic cells). These receptors recognize patterns such as pathogen- and danger-associated molecular patterns (PAMP and DAMP, respectively). The role of recognition prevails in antigen presentation, through intracellular signals is inavitable in the expression of histocompatibility antigens and costimulatory molecules, thus supporting the principal acivity of dendritic cells.

We learned many facts about regulatory $\mathrm{T}$ (Treg) and B (Breg) cells both at cell biological and molecular levels (Nimmerjahn and Ravetch 2008).

In the last decade we are facing with the evidences of microbiota/microbiome, a symbiotic microbial kingdom coexisting (and co-evolving) with many if not all eukariota organisms. Our view on basic axes of immune regulation (e.g. Th1-Th2 regulations) completed with the recognition of Th17-Treg balancies, as well.

Obviously, the recently uncovered elements of complement activation plays essential role in multiple events of immune regulation. Our earlier data suggested that the input through Fc $\gamma \mathrm{R}$ on murine myelod cells has a certain regulatory role in de novo $\mathrm{C} 3$ production. 
In this article, based on previous (1991-1992) findings we try to ask new questions in the light of our recent (2020) views and concepts in immunology.

\section{The question and results from 1991-1992}

Using selected murine myeloma proteins in vitro how the Fc $\gamma \mathrm{R}$ - mediated regulation affects the $\mathrm{C} 3$ biosynthesis by mouse peritoneal macrophages and a mouse monocytemacrophage cell line? What is the possible role of IL-6 in this process?

We do not go into methodological details, in 1991-1992 we used the appropriate immunological and molecular biology methods.

The results were shortly as listed below:

1. Both mouse $\operatorname{IgG} 2 \mathrm{a}$ and $\operatorname{IgG} 2 \mathrm{~b}$ upregulated the gene expression and biosynthesis of $\mathrm{C} 3$ in murine macrophages and an immortalized macrophage cell line. Other isotypes (IgG1 and IgG3) failed to influence significantly the $\mathrm{C} 3$ production.

2. Phorbol esther (even if alone was inhibitory) further enhanced the effect of $\operatorname{IgG} 2 \mathrm{a}$ and $\mathrm{IgG} 2 \mathrm{~b}$ on the $\mathrm{C} 3$ production.

3. Interleukin- 6 elevated the effect of $\operatorname{IgG} 2 a$ and $\operatorname{IgG} 2 b$ on the $\mathrm{C} 3$ secretion at post-transcriptional level, but alone did not resulted any enhancement.

4. A F(ab') fragment of an Fc $\gamma$ RII-specific monoclonal antibody strongly stimulated the $\mathrm{C} 3$ production, as well.

\section{Discussion from 1991-1992}

The binding of ligands to macrophage Fc $\gamma$ Rs generates transmembrane signals that trigger a wide array of activities, such as antibody-dependent cellular cytotoxicity, synthesis of hydrogen peroxide and other active oxygen intermediates, the release of inflammatory agents and the secretion of neutral proteases (Mellman 1988, Unkeless et al 1988). In spite of the ongoing formation of immune complexes of different composition in vivo, the possible effect of the occupancy of Fc $\gamma$ Rs by different IgG isotypes on $\mathrm{C} 3$ production has not been investigated so far (Lambris 1988). In the present study it is demonstrated that $\mathrm{IgG} 2 \mathrm{a}$ and $\lg \mathrm{G} 2 \mathrm{~b}$ subclasses selectively upregulate gene expression and secretion of $\mathrm{C} 3$ by mouse peritoneal macrophages and P388D1cells (Hetland 1986; Johnson and Hetland 1988). Our data show that IgG1 had no enhancing effect on $\mathrm{C} 3$ production, despite the fact that it also binds to FcyRIl like $\lg \mathrm{G} 2 \mathrm{~b}$, using human monocytes. It has been demonstrated (6) that the two ligands, human $\operatorname{IgG} 1$ and
IgG3 upon binding to the same receptor (FcyRI) with different affinity evokes different conformational changes in the receptor molecule. As a consequence of this process, signal transduction and the killing activity of the same cell is modulated by the isotype of $\operatorname{IgG}$ binding to the cell. The weak enhancing effect of IgG3 on $\mathrm{C} 3$ production could be the consequence ol the weak expression of FcgRIII on murine macrophages [2].

PMA treatment caused a significant inhibition in the case of both peritoneal macrophages and P388D1 cells. This finding is in contrast to that of Maison et al (1989) who found that the human monocytic cell line U937 is able to synthesise $\mathrm{C} 3$ after PMA-induced differentiation. This dissimilarity may be caused by the differential effect of PMA to modulate C3 gene expression by human and murine cells used in our studies. The mechanism of the inhibition of $\mathrm{C} 3$ production by murine macrophages is not known, however it seems to be independent of Fc $\gamma \mathrm{R}$ occupancy, since it occured in the control samples, as well.

IL-6 is known to induce the synthesis of acute phase proteins in hepatocytes and to facilitate the terminal differentiation (Falus et al 1990). Alone, IL-6 did not affect C3 biosynthesis by peritoneal macrophages. However, when added together with the different IgG isotypes a further enhancement of $\mathrm{C} 3$ secretion could be observed. C3 gene expression increased only in the case of macrophages co-cultured with IL-6 and IgG2a or IgG2b. This enhancement could be mediated by newly appearing Fc $\gamma$ Rs, since IL-6 is known to induce mRNA synthesis [9]. There is an unexplaned virtual controversy between the general costimulatory effect of IL-6 on the secretion but not on the gene expression (mRNA) of C3. Similarly it has been described that in the human hepatoma line HepG2 both IL-6 (and IL-1) alone enhances $\mathrm{C} 3$ production at the transcriptional level. When IL-6 is added together with IL-1 a striking synergism between the two cytokines results in augmentation of $\mathrm{C} 3$ secretion but not the increase in transcription. Further pulsechase experiments are required to clarify the exact level of the costimulation mediated by signals transduced via $\mathrm{Fc} \gamma \mathrm{R}$ and IL- 6 receptors in mouse peritoneal macrophages. One of the questions whether do the cells some craosstalk between Fc $\gamma \mathrm{R}$ and IL-6 receptors. New studies are required to answer this question analysing the common and separate signalling pathways of both receptors.

\section{(Further) Tentative questions and discussion from 2020}

The questions from 1991-1992 might be completed with recent (2020) approaches, such as: 
(1) What is the effect of Ig isotypes on hepatic $\mathrm{C} 3$ production among in vivo conditions in mice?

(2) Does the genetic background of mice modify the effect of $\mathrm{IgG}$ isopypes on $\mathrm{C} 3$ production?

(3) How the differently sized aggregated IgG isotypes act on the expression of $\mathrm{C} 3$ and other complement proteins, including inhibitors of complement activation pathways?

(4) How the secreted C3 influences the expression of Fc $\gamma$ RII (what is the effect backwards)? Does the newly sythetized $\mathrm{C} 3$ show an autocrine effect on macrophages?

(5) Does the activated $\mathrm{C} 3$ bind to complement receptors (CR1, CR3, CR4 or CRIg) on macrophages?

(6) Does the activated $\mathrm{C} 3$ bind to $\mathrm{C} 3 \mathrm{~b}$ acceptor (covalently) on macrophages?

(7) How the different isotypes influence the $\mathrm{C} 3$ productions in genetically modified $(\mathrm{KO})$ murine strains lacking Fc $\gamma$ RII?

(8) How about local opsonization (described first almost three decades ago, ( Ezekowitz et al (1983), Ezekowitz (2002)). It was shown that the macrophagederived, cleaved, third component of complement, iC $3 b$, assembled on the surface of pathogen in the close vicinity of macrophage. How does it relate to the effect of Ig isotypes?

(9) Do we reach similar results using in vitro human systems (human Ig isotypes, and human myeloid and hepatic cell lines?

(10) What about the crosstalks between signalling pathways of Fc $\gamma \mathrm{R}$ and IL-6 receptors

\section{Conclusion}

Based on the expansion of our knowledge and broadening of methodological repertoire probably new questions (e.g. some of those listed above) may provide a deeper understanding of interation the complement and FcR related territories of immunity. Nevertheless, the data described 29 years ago are since valid.

However, new facts would further enlarge our vision on the complex interactions within innate immunity.

Funding Open Access funding provided by Semmelweis University.

Open Access This article is licensed under a Creative Commons Attribution 4.0 International License, which permits use, sharing, adaptation, distribution and reproduction in any medium or format, as long as you give appropriate credit to the original author(s) and the source, provide a link to the Creative Commons licence, and indicate if changes were made. The images or other third party material in this article are included in the article's Creative Commons licence, unless indicated otherwise in a credit line to the material. If material is not included in the article's Creative Commons licence and your intended use is not permitted by statutory regulation or exceeds the permitted use, you will need to obtain permission directly from the copyright holder. To view a copy of this licence, visit http://creativecommons.org/licenses/by/4.0/.

\section{References}

Bajtay Z, Falus A, Erdei A, Gergely J (1992) Fc $\gamma$ R-Dependent regulation of the biosynthesis of complement $\mathrm{C} 3$ by murine macrophages: the modulatory effect of IL-6. Scand J Immunol 35:195-201. https://doi.org/10.1111/j.1365-3083.1992.tb02850.x

Ezekowitz RA, Bampton M, Gordon SJ (1983) Macrophage activation selectively enhances expression of Fc receptors for IgG2a. Exp Med 157:807-812. https://doi.org/10.1084/jem.157.2.807

Ezekowitz RA (2002) Local opsonization for apoptosis? Nat Immunol 3:510-512. https://doi.org/10.1038/ni0602-510

Falus A, Rokita H, Walcz E, Brozik M, Hidvegi T, Meretey K (1990) Hormonal regulation of complement biosynthesis in human cell lines II. Upregulation of the biosynthesis of complement components $\mathrm{C} 3$, factor $\mathrm{B}$ and $\mathrm{CI}$ inhibitor by interleukin- 6 and interleukin-1 in human hepatoma cell line. Mol Immunol 27:197-201. https://doi.org/10.1016/0161-5890(90)90115-g

Hetland G, Johnson E, Falk RJ, Eskeland T (1986) Synthesis of complement components C5, C6. C7, C8 and C9 it vitro by human monocytes and assembly of the terminal complement complex. Scand J Immunol 24:421-428. https://doi.org/10.1111/j.1365-3083.1986. tb02130.x

Holers VM (2014) (2014) Complement and its receptors: new insights into human disease. Annu Rev Immunol 32:433-459. https://doi. org/10.1146/annurev-immunol-032713-120154

Johnson E, Hetland G (1988) Mononuclear phagocytes have the potential to synthesize the complete functional complement system. Scand J Immunol 27:489-493. https://doi. org/10.1111/j.1365-3083.1988.tb02375.x

Koenderman L (2019) Inside-out control of Fc-receptors. Front Immunol 10:544. https://doi.org/10.3389/fimmu.2019.00544

Lambris JD (1988) The multifunctional role of C3, the third component complement. Immunol Today 9:387-393. https://doi. org/10.1016/0167-5699(88)91240-6

Maison CM, Villiers CL, Colomb MG (1989) Secretion, cleavage and binding complement component $\mathrm{C} 3$ by the human monocytic cell line U937. Biochem J 261:407-413. https://doi.org/10.1042/bj261 0407

Markiewski MM, DeAngelis RA, Lambris JD (2008) Complexity of complement activation in sepsis. J Cell Mol Med 12:2245-2254. https://doi.org/10.1111/j.1582-4934.2008.00504.x

Mellman IS (1988) Relationship between structure and function in the Fc receptor family. Curr Opin Immunol 1:16-25. https://doi. org/10.1016/0952-7915(88)90046-5

Nimmerjahn F, Ravetch JV (2008) Anti-inflammatory actions of intravenous immunoglobulin. Annu Rev Immunol 26:513-533. https:// doi.org/10.1146/annurev.immunol.26.021607.090232

Sjöholm AG, Jönsson G, Braconier JH, Sturfelt G, Truedsson L (2006) Complement deficiency and disease: an update. Mol Immunol 43:78-85. https://doi.org/10.1016/j.molimm.2005.06.025

Unkeless JC, Scigliano K, Freedman VH (1988) Structure and function of human and murine receptors for IgG. Ann Rev Immunol 6:251-281. https://doi.org/10.1146/annurev.iy.06.040188.001343 